\title{
STUDY OF THE CLOGGING PROCESS IN A SEMI-ARID REGION: WADI EL HIMMER, MOROCCO
}

\author{
MOHAMMED ZAIDI ${ }^{1,2}$, NASRE-DINE AHFIR ${ }^{1}$, ABDELLAH ALEM ${ }^{1}$, \\ BOUABID EL MANSOURI ${ }^{2} \&$ HUAQING WANG \\ ${ }^{1}$ Normandie University, France \\ ${ }^{2}$ Laboratoire de Geosciences des Resources Naturelles, Université Ibn Tofail, Faculté des Sciences, Morocco
}

\begin{abstract}
In semi-arid regions, managed aquifer recharge (MAR) is seen as an efficient solution among others for protecting groundwater resources. Clogging is one of the major issues that can reduce the durability of recharge facilities. As a consequence of clogging of soils by suspended matter, permeability, and porosity, and therefore exchange between surface water and groundwater are reduced. To our knowledge, few researchers have studied the mechanism of clogging of the MAR in a semi-arid region according to hydrologic conditions of the field. The main objective of the present work is to study the clogging process of recharge sites in a semi-arid region (Wadi El Himmer, Morocco). These recharge sites consist of a "Percolation Tank" and "Recharge Releases", which retard and distribute the flow to facilitate infiltration into a saturated zone. Field measurements are conducted to quantify the thickness of the surface deposits (cake) according to precipitation at different recharge sites. To realize these measurements, wooden pickets were implanted at different locations of the recharge sites. After 12 weeks of exposure to hydro-meteorological conditions, the thickness of the deposited (suspended matter) layer was measured on each picket. In order to facilitate the interpretation of results, the kriging method was used to interpolate obtained measurements. A significant variation in cake thickness was observed at each recharge site following the flow direction. The layer deposited is mainly dominated by red clays and silts. These results prompted us to investigate the impact of these deposits on the deep clogging.
\end{abstract}

Keywords: semi-arid region, managed aquifer recharge, clogging, Wadi El Himmer (Morocco).

\section{INTRODUCTION}

Growing population and the increased demand for water resources have resulted in a global trend of groundwater depletion. Arid and semi-arid climates are particularly susceptible, often relying on groundwater to support the needs of large urban centers or irrigated agriculture in the absence of sufficient surface water resources [1]. Also, natural recharge is intrinsically limited in these climates, and the predicted effects of climate change on recharge in these regions are highly uncertain [2]. In order to increase the security of groundwater resources, managed aquifer recharge (MAR) programs have been developed and implemented globally [3].

MAR is an engineering system that aims to inject water into an aquifer in order to increase groundwater supplies [4]. Other objectives of this approach include reducing marine intrusions, storing water and improving surface water quality. It was the subject of several research studies that addressed its various technical and economic [5], [6].

Clogging of the infiltrating surface and resulting reductions in infiltration rates are the bane of all artificial recharge systems [7]. Three mechanisms of clogging can be identified: (i) Physical or mechanical related to solid particle inputs [8], [9] and environmental compaction related to basin activities, water loads when the basin is filled and settling of sediment deposits themselves [10]; (ii) Biological by the growth of microorganisms (algae, biofilm, bacteria) at the infiltration surface or on a thin layer [11]; and (iii) Chemical often due to precipitation and dissolution of minerals can be used for bacterial development by significantly modifying the porous medium [12]. 
Several researches have been undertaken to study the clogging phenomenon in the field. Fetzer et al. [13] investigated the dynamics of clogging by comparing infiltration of silty fine particles and sandy fine particles, and they compared the results between laboratory and field experiments. They showed that the clogging it's more pronounced in field, due to a highly fluctuating water regime, a polydispersed suspension and a high concentration of suspended particles in compared with laboratory conditions. Casas-Mulet et al. [14] studied the main hydraulic factors and trends in fine sediment accumulation on a river by installing sediment collectors in a lateral gravel bar subject to irregular flow fluctuations in the river. They estimated an important horizontal intergravel transport contributed to a significant accumulation of fine sediments. Skolasińska [15] identified the post-depositional changes that have occurred in river deposits affected by forced infiltration of river water and provided examples of fouling microstructures that have formed in deposits affected by laboratory clogging and under natural conditions are also presented. She concluded that the decomposition of organic matter present in deposits or in infiltrating water is a very important factor controlling clogging.

Until now, and to our knowledge, few studies have investigated the clogging mechanisms in artificial recharge facilities in a semi-arid environment as a function of hydrometeorological conditions of the field. The main objective of present work is to study the clogging process of streambed (wadi El Himmer, Morocco) in two sites of the MAR. Field measures are being developed to evaluate the thicknesses de deposits (Cake) according to the rainfall.

\section{MATERIALS AND METHODS}

\subsection{Study area}

Berrechid plain is located in the center of Morocco. It extends to $1500 \mathrm{~km}^{2}$. For many years, this aquifer has been the subject of many geological and hydrogeological studies [16]-[18]. It's characterized by an arid to semi-arid climate, with an average temperature of $18^{\circ} \mathrm{C}$ [19]. The annual average rainfall varies from 280 to $310 \mathrm{~mm} /$ year [20]. The supply of aquifer is mainly through the direct infiltration of rainfall and runoff flows. Four main streams (Fig. 1) are used to recharge the aquifer during flood events: Boumoussa, Tamedrost, Mazer and El Himmer [18]. The last stream extends $27 \mathrm{~km}$ in length, mainly supplied by flows from rainfall and releases from El Himmer dam in the upstream.

In the inset photos (Fig. 1) is presented (A) the Percolation Tank which retard the flow to facilitate infiltration into saturated zone during runoff, and (B) the Wadi bed after infiltration. During the drying periods, cracks appears with different opening dimensions. Notice that the high of the embankment ( $\mathrm{S} 1$ and S3) was around $70 \mathrm{~cm}$ above the clogged streambed surface.

The surface deposits in the study area are generally dominated by aggregates topped with silty red clay, gravel and cobble [18]. The south-north geological section of the Berrechid aquifer is presented in Fig. 2 which is adapted from [21]. El Himmer wadi is equipped with an MAR system of two Percolation Tanks (S1 and S3) and two recharge releases (S2 and S4) constructed on the Wadi (cf. Fig. 1) to promote infiltration to the aquifer by the dam's releases in upstream (El Himmer Dam) and rainfall flows.

After more than ten years of use, a high volume of fine suspended particles transported by the flows, settle along the Wadi, particularly in the percolation basins (Percolation Tanks and Recharges Releases), thereby limiting the infiltration. 


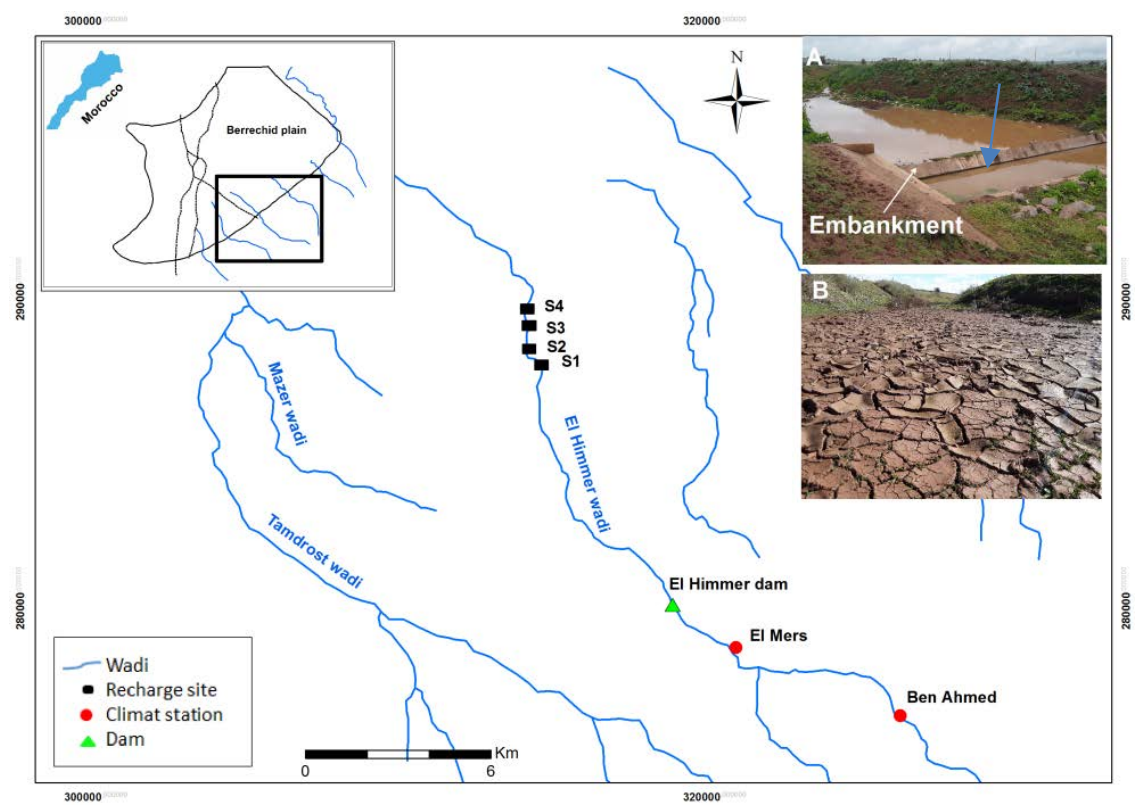

Figure 1: Study area at the southern limit of Berrechid aquifer (Morocco). Study sites are located along the length of El Himmer wadi (S1, S2, S3, and S3). (a) "Percolation Tank" which retard the flow to facilitate infiltration into saturated zone during runoff; (b) Wadi bed after infiltration.

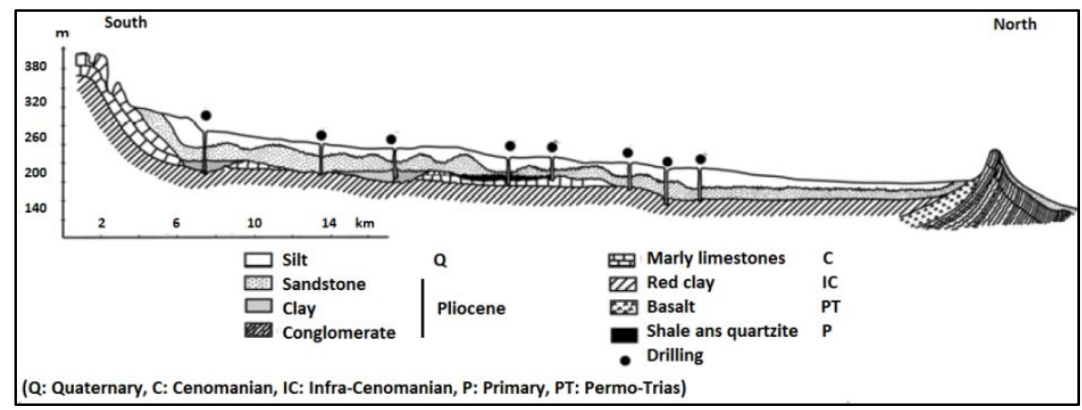

Figure 2: South-north geological section of the Berrechid aquifer. (Source: Adapted from Moullard and Hazan [21]).)

\subsection{Field investigations}

In the present study, two sites (site S1 and site S3) were selected which are spaced by $1 \mathrm{~km}$ each other. On each site, and over an area of $750 \mathrm{~m}^{2}(15 \times 50)$, pickets were implanted in different positions. The implantation of these Pickets was done on 20th October, 2018. The top of each Picket remained uncovered by $10 \mathrm{~cm}$ which permits to measure the thickness of the deposits after twelve weeks of exposure to hydro-meteorological conditions (19th 
January, 2019). A total of nineteen Pickets were implanted: eight pickets in the site S1 and eleven pickets in the site S3.

From 20th to 28th October, 2018 measurement of the Wadi bed soil hydraulic conductivity (Ks) was undertaken using a "double ring infiltrometer". These measurements were made at the surface of Wadi bed. A total of thirty measurements were done. The median values for the both sites, are presented in Table 1.

Table 1: Summary of the positions and characteristics of recharge sites studied.

\begin{tabular}{|c|c|c|c|c|}
\hline \multirow{2}{*}{ Location } & \multicolumn{2}{|c|}{ Lambert coordinates } & \multirow{2}{*}{ Studied area $\left(\mathrm{m}^{2}\right)$} & \multirow{2}{*}{$\mathrm{Ks}(\mathrm{m} / \mathrm{s})$} \\
\cline { 2 - 3 } & $\mathrm{x}(\mathrm{m})$ & $\mathrm{y}(\mathrm{m})$ & & \\
\hline Site 1 & 313686 & 287307 & $50 \times 15$ & $10^{-6}$ \\
\hline Site 3 & 313224 & 288314 & $50 \times 15$ & $10^{-5}$ \\
\hline
\end{tabular}

The daily rainfall time series, provided by the Bouregregreg and Chaouia Hydraulic Basin Agency (ABHBC), covering a period of eight months (between August 2018 and March 2019) is depicted in Fig. 3. This data was collected from the El Mers climate station $(x=320050 \mathrm{~m} ; \mathrm{y}=279150 \mathrm{~m})$ located at eight kilometers from the study area (cf. Fig. 1). The observation of the daily rainfall histogram indicates that the precipitation is highly variable for each month. The most humid period was October and November with an average of $76 \mathrm{~mm} / \mathrm{month}$. Since December, rainfall has become progressively less with $6.8 \mathrm{~mm}$ registered over the month of December. During the study period (20th October 2018 to 19th January 2019) the total rainfall was less than $120 \mathrm{~mm}$, with an average of $1.33 \mathrm{~mm} /$ day.

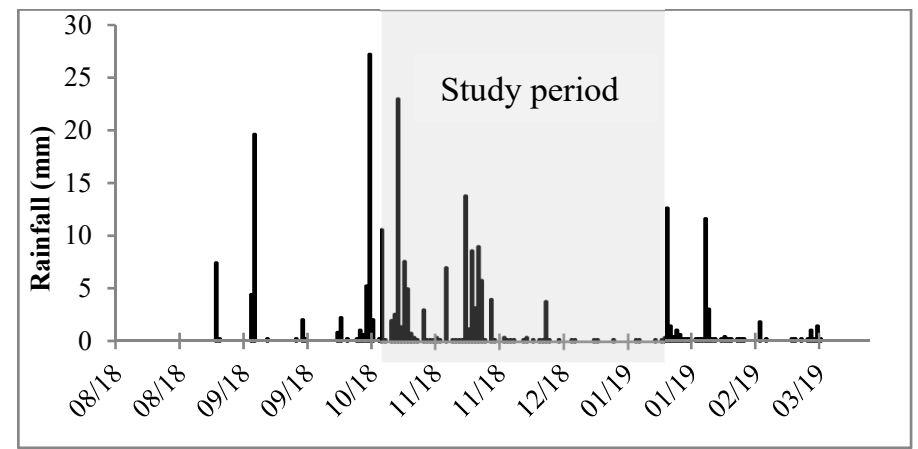

Figure 3: Daily rainfall in Wadi El Himmer from 1st August 2018 to 24th March 2019.

Water samples were taken from the water retention tanks at the two recharge sites to calculate the concentration of suspended matter carried by the flows. The results indicate that the concentration at site $\mathrm{S} 1$ is around $1.4 \mathrm{~g} / \mathrm{L}$, while for site $\mathrm{S} 3$ it does not exceed 1.1 $\mathrm{g} / \mathrm{L}$.

\section{RESULTS AND DISCUSSION}

After twelve weeks of exposure to climatic conditions, the thickness of the deposited (suspended matter) layer was measured on each picket (Fig. 4). Cracks appeared after the rainy period (mainly between late November and mid-January). 


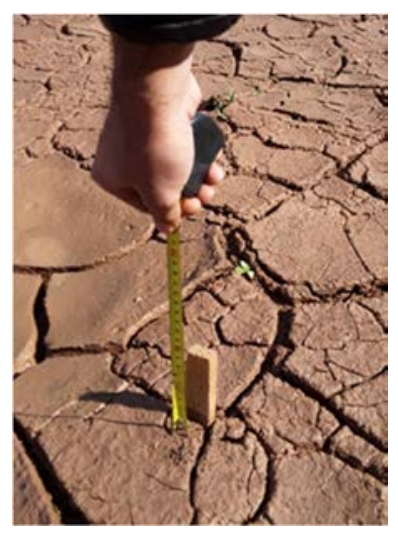

Figure 4: Deposit measuring on a picket.

\subsection{Thickness of deposits}

Table 2 summarizes the thickness of sediments accumulated for all pickets in the studied infiltration sites. Deposits accumulation varied significantly as a function of the distance to the limit of percolation tank (embankment). For both studied sites, sediments thickness varied between 0 and $12 \mathrm{~cm}$, by following flow direction from upstream to the limit of the percolation tanks. Several factors influence the variation in deposition thickness of suspended particles carried by the flows. Many factors can affect the depth's cake such as streambed topography, presence of preferential flow and vegetation density, etc.

Table 2: Deposit thickness on pickets.

\begin{tabular}{|c|c|c|c|c|c|c|c|}
\hline \multirow{12}{*}{ Site S1 } & $\begin{array}{l}\text { Picket } \\
\text { name }\end{array}$ & $\begin{array}{c}\text { Distance }(\mathrm{m}) \\
\text { picket/ } \\
\text { embankment }\end{array}$ & $\begin{array}{l}\text { Thickness } \\
\text { (cm) }\end{array}$ & \multirow{12}{*}{ Site S3 } & $\begin{array}{l}\text { Picket } \\
\text { name }\end{array}$ & $\begin{array}{l}\text { Distance }(\mathrm{m}) \\
\text { picket/ } \\
\text { embankment }\end{array}$ & $\begin{array}{l}\text { Thickness } \\
(\mathrm{cm})\end{array}$ \\
\hline & A & 6 & 4.5 & & $\mathrm{~K}$ & 3 & 4 \\
\hline & B & 6 & 2.5 & & I & 3 & 12 \\
\hline & $\mathrm{C}$ & 18 & 2.5 & & $\mathrm{~J}$ & 3 & 1.7 \\
\hline & $\mathrm{D}$ & 22 & 3.5 & & $\mathrm{~L}$ & 14 & 4.5 \\
\hline & $\mathrm{E}$ & 30 & 2.5 & & $\mathrm{M}$ & 14 & 3 \\
\hline & $\mathrm{F}$ & 32 & 3 & & $\mathrm{~N}$ & 14 & 0 \\
\hline & $\mathrm{G}$ & 32 & 0 & & $\mathrm{O}$ & 26 & 1 \\
\hline & $\mathrm{H}$ & 40 & 1.5 & & $\mathrm{P}$ & 37 & 0 \\
\hline & & & & & $\mathrm{Q}$ & 45 & 1.3 \\
\hline & & & & & $\mathrm{R}$ & 50 & 1.3 \\
\hline & & & & & $\mathrm{S}$ & 50 & 1.3 \\
\hline
\end{tabular}

Correlation by kriging was used to interpolate the layer thickness (cake) formed on each recharge site, and the obtained results are presented in Fig. 5. It is noted that the largest thickness of the deposits measured reaches $12 \mathrm{~cm}$ in the site S3. This may be due to the topography of the site, with the presence of a bowl-shaped in which a significant volume of water was stagnated over a long period. Roughly speaking, thickness of deposits in the site 
$\mathrm{S} 1$ is greater on the right bank than on the left one. This may be due to the presence of a preferential path and/or the lack of vegetation on the right bank, which has contributed to the surface erosion from the bank during rainfall and consequently to a high accumulation compared to the left bank.
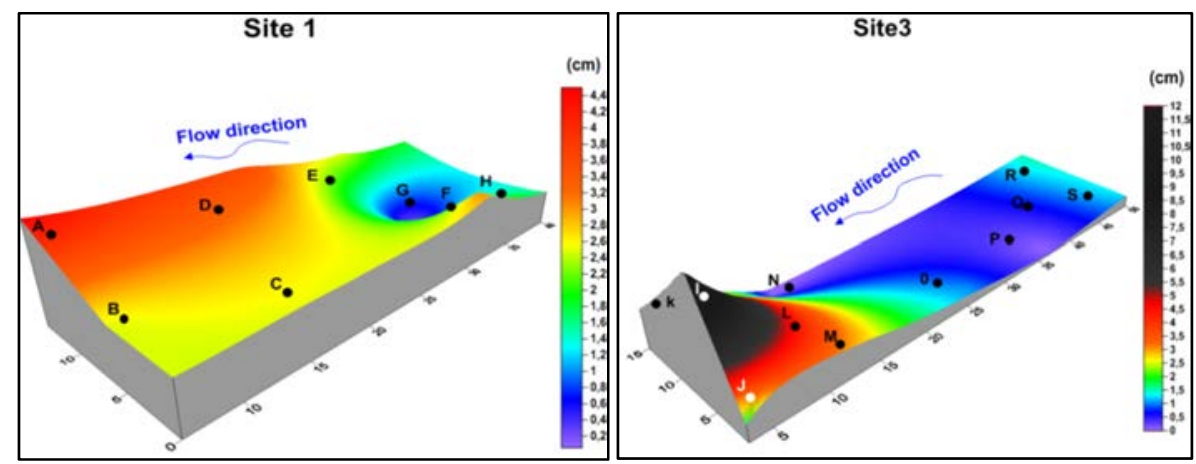

Figure 5: Cake deposited on the both infiltration sites.

It is also noted that with low rainfall of 3 months, the average thickness of the cake on both sites is around $2.5 \mathrm{~cm}$. This indicates the rate of surface clogging of these recharge sites by suspended particles. This can minimize the vertical infiltration of surface water into the unsaturated zone and therefore the groundwater recharge.

\subsection{Particles size distribution}

The particle size distribution (PSD) of the cake was determined by using the Mastersizer 2000 particle size analyzer (Malvern instruments). Samples used for the PSD of the deposits were taken in the cake around the pickets. Fives samples were analyzed. The results of the PSD (Fig. 6) indicate that the particles are characterized by a large size distribution within a range between $0.2 \mu \mathrm{m}$ and $600 \mu \mathrm{m}$. The median diameter $\mathrm{d}_{50}$ equals to $7.2 \mu \mathrm{m}, \mathrm{d}_{10}$ equals $0.76 \mu \mathrm{m}$, and $\mathrm{d}_{90}$ equals $150 \mu \mathrm{m}$. The deposited particles consist of $20 \%$ clay, $51 \%$ silt, $22 \%$ of fine sand ( $>63$ to $200 \mu \mathrm{m})$, and $6 \%$ of medium sand ( $>200$ to $630 \mu \mathrm{m})$ [22].

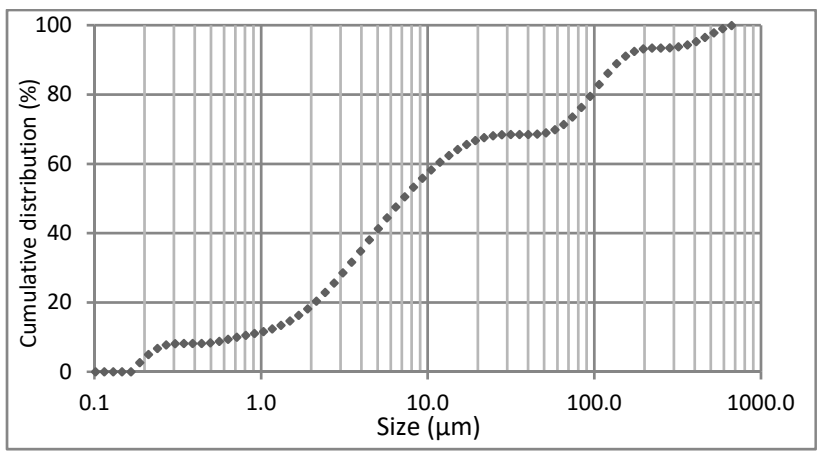

Figure 6: Particle size distribution of the particles constituting the cake. 


\section{CONCLUSION}

Investigation undertaken in the recharge sites on wadi El Himmer during 12 weeks indicates that although the low rainfall, the thickness of the accumulated sediments is important, with an average of $2.5 \mathrm{~cm}$. Cake thickness developed at both sites increases in the direction of flow, and are probably influenced by the variations of the sites topography, presence of preferential flow paths, and the density of the vegetation. The sediments are generally dominated by silt and clay.

The particle size distribution is characterized by a large distribution, with a significant proportion under $10 \mu \mathrm{m}$.

Considering the rapid clogging of the studied area, further detailed investigations of the clogging mechanisms in the sub-surface are still being investigated in the field. The concentration and the PSD of the infiltrated particles, hydraulic conductivity evolution of the soil, hydrodynamics conditions, and other factors influencing the percolation tanks clogging are among the parameters studied.

\section{ACKNOWLEDGEMENTS}

This study was supported PHC TOUBKAL project (18/74 number 38951NJ). The authors wish to thank the Bouregregreg and Chaouia Hydraulic Basin Agency (ABHBC) for the availability of daily rainfall data.

\section{REFERENCES}

[1] Famiglietti, J., The global groundwater crisis. Nature Climate Change, 4(11), pp. 945948, 2014.

[2] Taylor, R.G. et al., Ground water and climate change. Nature Climate Change, 3(4), pp. 322-329, 2013

[3] Stefan, C. \& Ansems, N., Web-based global inventory of managed aquifer recharge applications. Sustainable Water Resources Management, 4(2), pp. 153-162, 2018.

[4] Bouwer, H., Artificial recharge of groundwater: Hydrogeology and engineering. Hydrogeology Journal, 10(1), pp. 121-142, 2002.

[5] Marino, M.A., Artificial groundwater recharge, I. Circular recharging area. Journal of Hydrology, 25(3-4), pp. 201-208, 1975.

[6] Detay, M., Rational groundwater reservoir management, the role of artificial recharge. Artificial Recharge of Groundwater II. ACSE: New York, pp. 231-240, 1995.

[7] Baveye, P., Vandevivere, P., Hoyle, B.L., DeLeo, P.C. \& de Lozada, D.S., Environmental impact and mechanisms of the biological clogging of saturated soils and aquifer materials. Critical Reviews in Environmental Science and Technology, 28(2), pp. 123-191, 1998.

[8] Rinck-Pfeiffer, S., Ragusa, S., Sztajnbok, P. \& Vandevelde, T., Interrelationships between biological, chemical, and physical processes as an analog to clogging in aquifer storage and recovery (ASR) wells. Water Research, 34(7), pp. 2110-2118, 2000.

[9] Siriwardene, N.R., Deletic, A. \& Fletcher, T.D., Clogging of stormwater gravel infiltration systems and filters: Insights from a laboratory study. Water Research, 41(7), pp. 1433-1440, 2007.

[10] Gonzalez-Merchan, C., Barraud, S., Le Coustumer, S. \& Fletcher, T., Monitoring of clogging evolution in the stormwater infiltration system and determinant factors. European Journal of Environmental and Civil Engineering, 16(sup1), pp. s34-s47, 2012. 
[11] Nie, J.Y., Zhu, N.W., Zhao, K., Wu, L. \& Hu, Y.H., Analysis of the bacterial community changes in soil for septic tank effluent treatment in response to bioclogging. Water Science and Technology, 63(7), pp. 1412-1417, 2011.

[12] Mays, D.C. \& Hunt, J.R., Hydrodynamic and chemical factors in clogging by montmorillonite in porous media. Environmental Science and Technology, 41(16), pp. 5666-5671, 2007.

[13] Fetzer, J., Holzner, M., Plötze, M. \& Furrer, G., Clogging of an Alpine streambed by silt-sized particles: Insights from laboratory and field experiments. Water Research, 126, pp. 60-69, 2017.

[14] Casas-Mulet, R., Alfredsen, K.T., McCluskey, A.H. \& Stewardson, M.J., Key hydraulic drivers and patterns of fine sediment accumulation in gravel streambeds: A conceptual framework illustrated with a case study from the Kiewa River, Australia. Geomorphology, 299, pp. 152-164, 2017.

[15] Skolasińska, K., Clogging microstructures in the vadose zone-laboratory and field studies. Hydrogeology Journal, 14(6), pp. 1005-1017, 2006.

[16] Hazan, R. \& Moullard, L., Notice hydrogéologique de la plaine de Berrechid. Office national des irrigations. Services des ressources en eau, Rabat, 1962.

[17] Ruhard, J.P., Chaouia et la plaine de Berrechid (Tome 1). Ressources en Eau du Maroc. Notes et Mémoire du Service Géologique, 231, 1975.

[18] El Mansouri, B., Structure et modélisation quantitative de l'aquifère de Berrechid (Maroc): Validation par l'approche géostatistique, Doctoral dissertation, Lille 1, 1993.

[19] El Gasmi, E.H., El Mansouri, B. \& Tammal, M., Surface flows in the plate of SettatBen Ahmed and the plain of Berrechid: Endoreic hydrography. International Journal of Innovation and Scientific Research, 9(1), pp. 40-53, 2014.

[20] El Assaoui, N., Amraoui, F. \& El Mansouri, B., Modélisation numerique de l'effet des changements climatiques sur la nappe de Berrechid (Maroc). European Scientific Journal, 11(23), 2015.

[21] Moullard, L. \& Hazan, R., Nappe phréatique de la nappe de Berrechid. Assoc. Inter. Hydrol. Sc. Helsinki, 52, pp. 105-114, 1960.

[22] AFNOR, Geotechnical investigation and testing identification and classification of soil. NF EN ISO 14688-1, P 94-400-1, 2003. 